Article

\title{
Environmental and Economic Benefit Analysis of an Integrated Heating System with Geothermal Energy-A Case Study in Xi'an China
}

\author{
Qingyou Yan and Chao Qin* \\ Beijing Energy Development Research Center, School of Economic and Management, \\ North China Electric Power University, Beijing 102206, China; yanqingyou@263.net \\ * Correspondence: qinchao08@163.com; Tel.: +86-152-1074-6522
}

Received: 7 November 2017; Accepted: 6 December 2017; Published: 9 December 2017

\begin{abstract}
Due to the increase in environmental problems and air pollution during the heating period, it is important to promote clean heating in cold regions, thereby meeting the heating demand in a green manner. In order to allocate resources more effectively and facilitate the consumption of renewable energy, this paper designs an integrated heating system that incorporates geothermal energy into the framework of an integrated energy system of electricity, heating, and gas. An analysis of the environmental and economic benefits indicates that the system reduces pollutant emissions and decreases the cost of urban heating. Using an example of central heating of residential buildings in $\mathrm{Xi}^{\prime}$ an, the paper conducts a scenario analysis based on the gas peak-shaving ratio and the ratio of geothermal heating loads to basic heating loads. The results demonstrate that the environmental and economic benefits of the integrated heating system are higher compared to central heating using coal-fired boilers. In addition, this paper conducts a sensitivity analysis of the heat source to the price factors and the load ratios. The results show that the operating costs of the integrated heating system are most sensitive to the natural gas price and the gas peak-shaving ratio. Therefore, an optimum natural gas peak-shaving ratio can be determined.
\end{abstract}

Keywords: integrated heating system; cogeneration; geothermal energy; sensitivity analysis

\section{Introduction}

China is a big country with large coal consumption, especially in cold regions, and heating with coal-fired boilers causes serious pollution problems during the winter. In this context, the demand for heating, as well as environmental considerations, have made it an important issue to improve the district heating system and achieve clean heating. Especially in recent years, with the proposition of the "energy internet" and people's awareness of environmental protection, a coordinated integrated energy system is increasingly attracting attention from all sectors of the community. The purpose of an integrated energy system is to construct an "energy internet" by realizing the collaborative coupling of many types of energy including electricity, gas, cold, heat, and other forms of energy in every segment of production, transmission, and consumption; this approach is aimed at achieving sustainable energy development and solve the energy crisis and various environmental problems [1-3]. Using the framework of an integrated energy system, scholars have optimized the typical energy systems comprised of electricity/heat/natural gas $[4,5]$ and have explored the use of renewable energy for achieving clean heating and solve winter heating problems in cold regions [6-8].

At present, the common heating system in China is based on thermal power plants or large coal-fired boiler rooms and uses centralized coal-fired boiler rooms as the peak-shaving heat source in primary networks [9]. Cogeneration is the most commonly used central heating source and accounts for $62.9 \%$ of China's current urban central heating sources [10]. During cogeneration, the high-quality 
thermal energy is applied to power generation and the low-quality thermal energy is used for heating. Compared to power generation with pure condensing units, cogeneration is better able to save fuel and improve energy efficiency [11-13]. However, the method has deficiencies such as insufficient heat transfer capacity, high cost, and low penetration [14]. Because of that, and under the pressure of energy savings and emission reduction, some scholars have optimized the cogeneration system from a technical point of view [15-17], while other scholars have introduced renewable energy such as solar energy, natural gas, and geothermal energy into the heating system to reduce environmental pollution [18-20]. Renewable sources represent an effective alternative to fossil fuels for preventing resources depletion and for reducing air pollution, for example, Alam et al., discussed the potential application of solar power systems for residential buildings in Barcelona in Spain and illustrated that the system can assist targeting of urban environment [21], Muniak et al., 2017 analyzed the cost of preparation of domestic hot water in a single-family home in Krakow in Poland and substantiated its economic viability $[22,23]$. Both domestic and international studies have shown that a hybrid heating system that combines renewable energy with traditional cogeneration can achieve higher overall efficiency than cogeneration and conventional power plants and better meet the heating requirements of buildings [24-27]. This paper aims to analyze the environmental and economic benefit of an integrated heating system with geothermal Energy.

As a clean energy, geothermal energy also occupies a certain proportion in urban heating and has received increased attention because of its (i) environmentally friendly aspect as an alternative to fossil fuels; (ii) abundant resources; and (iii) convenient access [28,29]. A ground-source heat pump (GSHP) is the main equipment that absorbs and transforms the shallow geothermal heat source, thereby providing winter heating or summer cooling [30]. According to surveys, China is one of the countries where installing ground-source heat pumps and using them for direct heating and cooling are relatively common [31]. Numerous scholars have analyzed and evaluated the heating capacities of GSHP systems [32-36]. For example, Arat and Arslan (2017) analyzed the economic benefits of a GSHP using the life cycle cost (LCC) and the net present value (NPV); the authors calculated the number of dwellings that could be heated and optimized the district heating system aided by a ground-source heat pump using a novel artificial neural network (ANN) [37,38]. Keçebaş (2016) investigated a geothermal district heating system by using an exergo-environmental analysis and found that the environmental impacts of the system were reduced when the ambient temperature decreased and the wellhead temperature increased [39]. Yürüsoy and Keçebaş (2017) further evaluated the components of a district heating system with geothermal energy from an environmental point of view and proposed some recommendations for reducing the environmental impacts, such as improvements in heat exchangers [40]. These studies have shown that the geothermal heating, whether for energy conservation or emission reduction, has clear advantages compared to central heating using traditional boiler rooms. On the one hand, the use of geothermal energy can strengthen the promotion of electricity use, help achieve the replacement of coal, oil, and other energy sources by electricity, and significantly improve the level of electrification. On the other hand, it can greatly reduce the pollutant emissions resulting from coal, oil, and other energy sources that are used directly for terminal energy consumption and promote the use of renewable energy; these effects are conducive to increasing energy efficiency and improving the quality of the urban environment [41]. However, it should be noted that the geothermal and economic conditions are different in different regions; therefore, the specific benefit evaluations of a heating system should be made on a case-by-case basis. It is well known that the performance of a GSHP is dependent to a great extent on various parameters such as geology and climatic conditions. Thus, the influences of temperature, pressure, flow rate, load, and price on the performance of heating system are important research focuses [42-44].

In summary, an integrated heating system comprised of electricity, heat, and gas is the future development trend. The power system and heating system are closely linked, mutually coupled, and complementary in their characteristics; their integration can enhance the power transmission capacity. Moreover, geothermal energy, which is clean and environmentally friendly, can effectively reduce 
environmental impacts. However, the integrated heating system in China has not been studied in depth and there is a lack of quantitative analysis regarding its environmental benefits; in addition, the economic benefits have been analyzed mostly in terms of equipment costs or operating costs. As a consequence, the environmental and economic benefits resulting from the use of renewable energy in an integrated heating system cannot be determined.

The main object of this study is to design an integrated heating system with geothermal energy by introducing gas (mainly natural gas), electricity, and geothermal energy into the district heating system and verify its superiority through environmental and economic benefit analysis. In details, this paper presents feasibility of the integrated heating system with geothermal energy and establishes environmental and economic benefit evaluation models according to the heating load during a heating period. Using the city of $\mathrm{Xi}^{\prime}$ an as an example, this paper compares the environmental and economic benefits of the integrated heating system and the traditional coal-fired boiler heating under different natural gas peak-shaving ratios and discusses the technical and economic superiority of the integrated heating system. In addition, this paper discusses the influences of price factors and load ratios on the operating cost of system by using sensitivity analysis. The results demonstrate that the environmental and economic benefits of the integrated heating system are higher compared to central heating using coal-fired boilers and the operating costs of the integrated heating system are most sensitive to the natural gas price and the gas peak-shaving ratio. This study provides a reference for policy makers constructing integrated heating system.

The rest of the paper is organized as follows: Section 2 designs the integrated heating system, Section 3 constructs the environmental and economic benefit evaluation model; Section 4 conducts scenario analysis using $\mathrm{Xi}^{\prime}$ an China as example, Section 5 analyzes the sensitivity of heat sources to fuel prices and load ratios, Section 6 closes with a summary and conclusion.

\section{Integrated Energy System Design}

\subsection{Integrated Energy System Containing Electricity, Heating, and Gas}

An urban integrated energy system of electricity, heating, and gas comprises the city's power grid, heating network, and natural gas network (Figure 1). Although the transportation networks for the different energy types are not connected, the system still can be developed by energy conversion. For instance, cogeneration supplies heat and power at the same time and gas power plants and gas-fired boilers convert gas into electricity and heat simultaneously. The distributed energy utilization system based on solar and GSHP convert renewable energy into electricity and heat. Due to urban expansion, the city has seen a rapidly increasing heating load, electricity load, gas load, and a higher peak-valley ratio. Thus, the integrated energy system will have an impact on the various types of loads and provides the following three advantages:

First, it would increase the proportion of renewable energy or clean energy in the terminal energy consumption and the promotion of natural gas, geothermal energy, and solar energy will reduce the use of coal-fired boilers and the resulting environmental pollution.

Second, it conduces to the proportion of required electricity and promotes the policy of energy substitution in China. A main content of the energy substitution policy is "replacing coal by electricity" which is essentially a change of energy consumption mode and it means that using electric energy instead of coal, oil, natural gas and other fossil energy in the aspect of energy consumption, thereby maximizing the proportion of electric energy in terminal energy consumption.

Third, it helps to improve energy efficiency and reduce energy waste. For example, the thermal efficiency of coal-fired boilers is approximately $70 \%$, while the efficiency of gas-fired boilers can reach $90 \%$. 


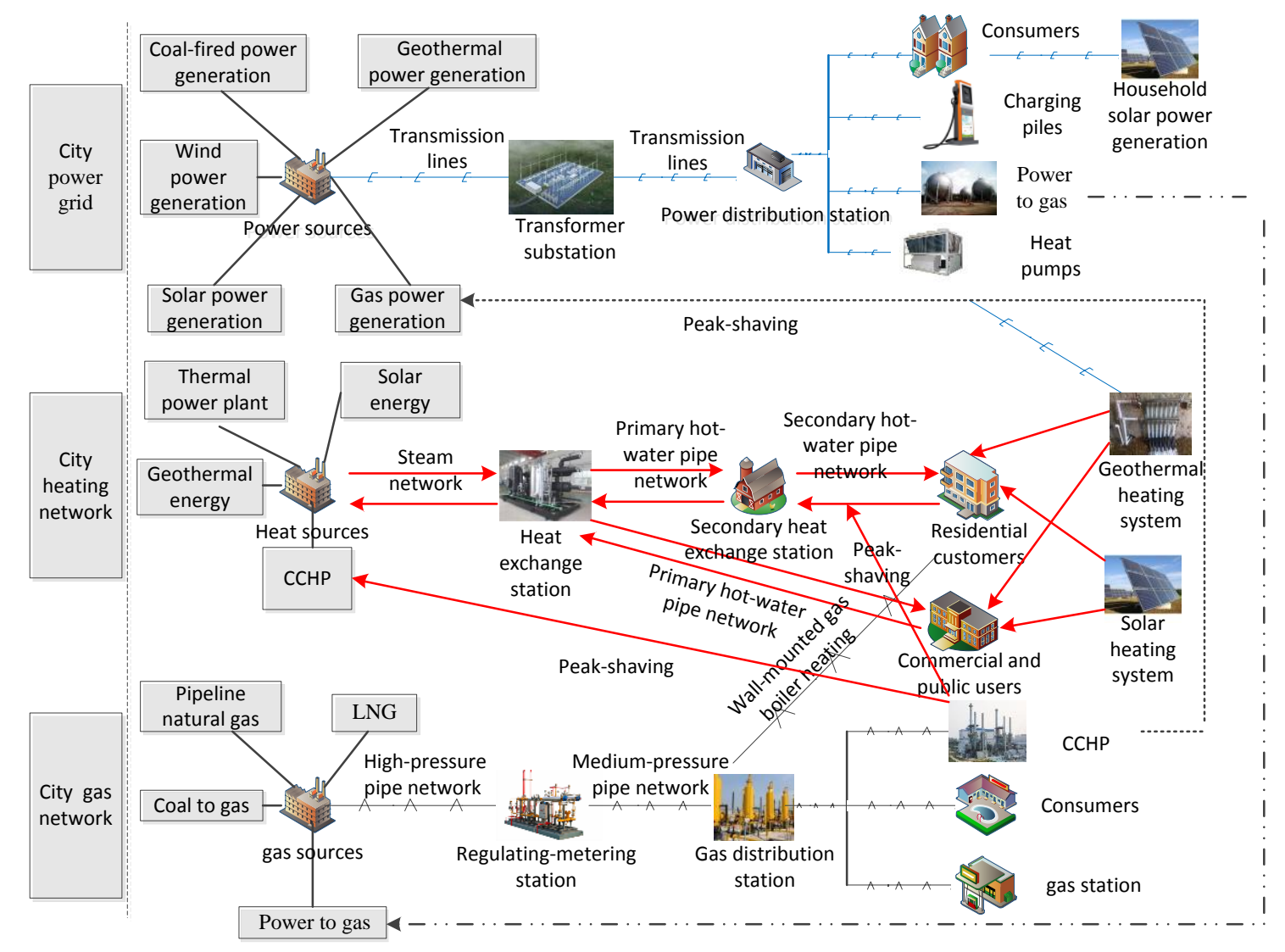

Figure 1. Sketch of urban integrated energy system comprised of electricity, heat, and gas (CCHP: combined cooling heating and power, LNG: liquefied natural gas).

\subsection{Integrated Heating System with Geothermal Energy}

At present, the heating requirements of China's northern cities are mostly provided by coal-fired boilers and/or thermal power plants during the heating season. However, with the rapid progress of urbanization and the increase in built-up areas, numerous problems have arisen such as a shortage of heat supply and a saturation of the pipeline transmission capacity. Furthermore, because of increasing environmental protection measures, coal-fired boilers are no longer built in many areas. Therefore, a new heating system is required to support the heating load supplied in the past by coal-fired boilers.

Introducing gas (mainly natural gas), electricity, and geothermal energy into the heating system can effectively solve the problem of an insufficient capacity of city heating and reduce pollutant emissions. As shown in Figure 2, the basic heat source of an urban integrated heating system is a thermal power plant. A gas-fired boiler is the peak-shaving heat source that can be connected to the primary or secondary network. In this study, we assume that the gas-fired boiler is connected to the primary network (Figure 2). In addition, the ground-source heat pump (GSHP) extracts the geothermal energy by using electricity and the derived heat is combined with the hot water in the secondary network. The GSHP represents the terminal basic load, it not only can make full use of the geothermal energy, which is clean and renewable but also can effectively alleviate the rapid decline in soil temperature using peak-shaving of the gas-fired boiler in the winter [45]. At the stage with low soil temperature, the peak shaving boiler puts into operation with the heat pump, and when soil temperature lower, it runs only with the peak heat source and heat pumps stopped, thereby enhancing the efficiency of the GSHP and the operating performance of the heating system. 


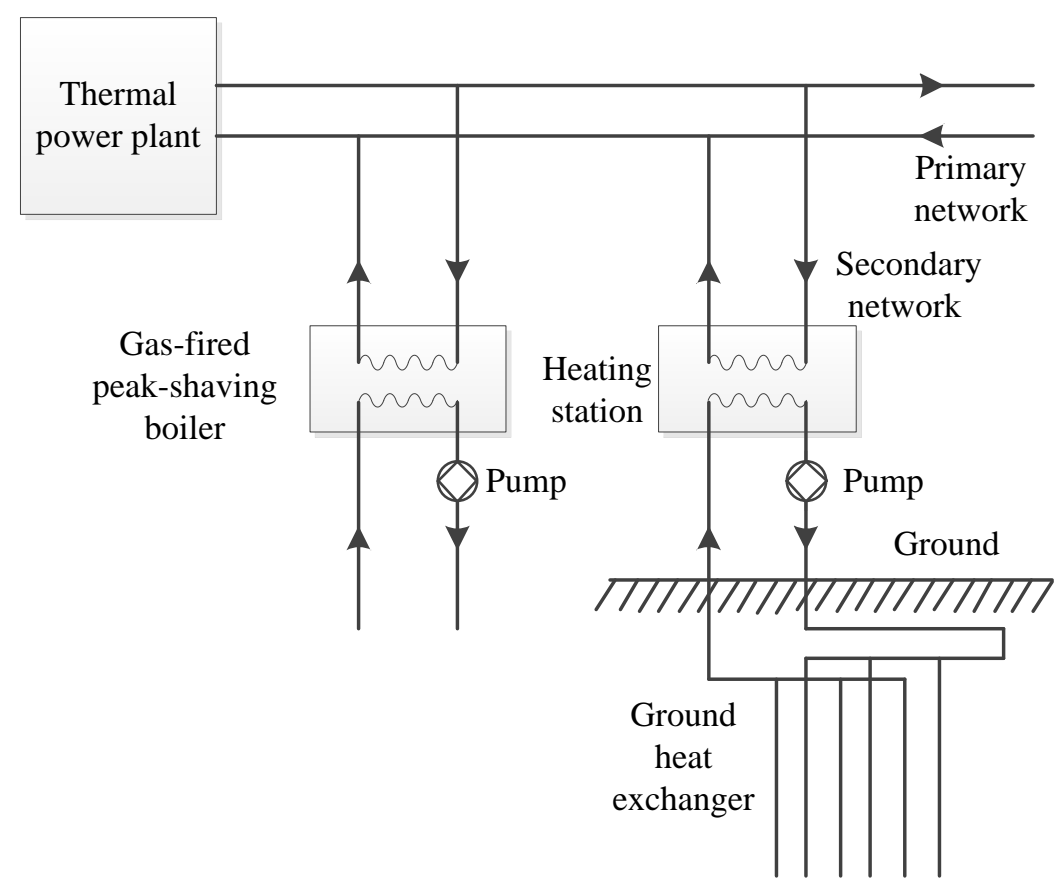

Figure 2. Schematic diagram of urban integrated heating system.

\section{Environmental and Economic Benefit Analysis}

\subsection{Heating Load during the Heating Period}

The heat consumption and the design load for heating of buildings are not only related to the local outdoor air temperature but are also affected by the area of the building envelope, the heat transfer coefficient, orientation, wind speed, and other factors. The average heating load and heat consumption during a heating period are obtained from the following equations:

$$
\begin{gathered}
Q_{h, a}=Q_{h} \frac{t_{i}-t_{a}}{t_{i}-t_{o, h}} \\
Q_{h}^{a}=\sum_{n=1}^{N} Q_{h, a} \times T_{n}=\sum_{n=1}^{N} Q_{h} \frac{t_{i}-t_{a}}{t_{i}-t_{o, h}} \times T_{n}
\end{gathered}
$$

where $Q_{h, a}$ is the average heating load during the heating period (in $\mathrm{kW} / \mathrm{m}^{2}$ ); $Q_{h}$ is the design load for heating the buildings (in $\mathrm{kW} / \mathrm{m}^{2}$ ); $Q_{h}^{a}$ is the heat consumption (in $\mathrm{kWh} / \mathrm{m}^{2}$ ); $t_{i}$ is the indoor temperature for calculation; $t_{a}$ is the mean outdoor temperature during the heating period; $t_{o, h}$ is the outdoor temperature for calculation; $T_{n}$ are the heating hours of the $n$-th day, and $N$ is the days of heating period.

After we obtain the average heating load and heating area of the buildings during the heating period, we calculate the heating load of the integrated heating system using the following expression:

$$
\begin{gathered}
Q=Q_{h, a} \times S \\
Q=Q_{b, C H P}+Q_{b, p}+Q_{f}
\end{gathered}
$$

where $S$ is the heating area (in $\mathrm{m}^{2}$ ), $Q_{b, C H P}$ is the basic heating load of the thermal power plant (in $\mathrm{kW}), Q_{b, p}$ is the basic heating load of the ground-source heat pump, and $Q_{f}$ is the heating load of the gas peak-shaving heat source. 


\subsection{Environmental Benefit Evaluation Model}

The main objectives of developing an integrated heating system are (i) to replace the coal with gas, geothermal energy, and other clean energies; (ii) to promote cogeneration; (iii) to enhance the efficiency of coal utilization; and (iv) to speed up the replacement of coal-fired boilers. Therefore, the environmental benefits are mainly measured by the reduction of coal used under the same heating load and the decreased emissions of nitrogen oxides, sulfur dioxide, and total suspended particulates (TSP).

Based on the calculated heating load of the integrated heating system $(Q)$ and the coal consumption rate of the thermal power plant $\left(\lambda_{C H P, h}\right)$, the coal consumption of the coal-fired boiler and the thermal power plant can be respectively determined as follows:

$$
\begin{gathered}
B_{c}=\frac{Q \times T}{Q_{d w, c} \times \eta_{c}} \\
B_{C H P, h}=Q_{b, C H P} \times T_{b, C H P} \times \lambda_{C H P, h}
\end{gathered}
$$

where $Q_{d w, c}$ is the low heating value of coal, $\eta_{c}$ is the coal-fired boiler efficiency, $T$ is the heating hours of the coal-fired boiler, and $T_{b, \mathrm{CHP}}$ is the heating hours of the thermal power plant.

The gas consumption of a gas-fired peak-shaving boiler during the heating period is defined as:

$$
V_{g}=\frac{Q_{f} \times T_{f}}{Q_{d w, g} \times \eta_{g}}
$$

where $T_{f}$ is the peak-shaving time of the gas-fired boiler, $Q_{d w, g}$ is the low heating value of gas, and $\eta_{g}$ is the gas-fired boiler efficiency.

Also, in consideration of various types of power generation such as thermal, hydro, and wind, we use $\theta_{\text {coal }}$ to represent the proportion of thermal power generation for electricity generation and $\sigma_{\text {coal }}$ to denote the coal consumption rate of the thermal power generation. Subsequently, the coal consumption per unit electricity consumption can be calculated as:

$$
\lambda_{e}=\theta_{\text {coal }} \cdot \sigma_{\text {coal }}
$$

The coal consumption of the GSHP during the heating period can be further characterized as:

$$
B_{p}=\frac{Q_{b, p} \times T_{b, p}}{\gamma_{c o p}} \times \lambda_{e}
$$

where $\gamma_{c o p}$ is the heating coefficient of the GSHP and $T_{b, p}$ is the heating hours of the GSHP.

Assuming that 1 cubic meter of natural gas is equivalent to $1.214 \mathrm{~km}$ of standard coal at normal atmospheric pressure and $273.15 \mathrm{~K}$, the amount of coal saved by all users, that is, the difference between the coal consumption of coal-fired boilers and the coal consumption of the integrated heating system $(\Delta B)$ can be characterized as:

$$
\Delta B=B_{\mathcal{C}}-B_{C H P, h}-1.214 \times V_{g}-B_{p}
$$

Moreover, the emission reduction of a pollutant during a heating season $E_{\mathrm{er}, \mathrm{X}}(\mathrm{X}$ respectively refers to $\mathrm{NO}_{\mathrm{x}}, \mathrm{SO}_{2}$, and TSP) is given by:

$$
E_{\mathrm{er}, \mathrm{X}}=\Delta B \cdot \delta \mathrm{X}
$$

where $\delta$ X respectively refers to the unit coal consumption of nitrogen oxide, sulfur dioxide, and TSP, and $\Delta B$ is the change in coal consumption before and after substitution by natural gas. 
The main emissions of coal fired are air pollutants including nitrogen oxides, sulfur dioxide and TSP, and greenhouse gases such as carbon dioxide. In this paper, main air pollutants are considered as the focus of environmental benefits evaluation. In order to analyze the correspond economic benefits resulting from the reduction of pollutants, this paper calculated the government charges for pollutant discharge, thus to study the economic efficiency of the integrated heating system.

\subsection{Economic Benefit Evaluation Model}

Due to a "no coal zone" in the North of China, coarse coal particle combustion is prohibited and the elimination of small coal-fired boilers is accelerated. An integrated heating system based on a thermal power plant and assisted by natural gas, geothermal energy, and electricity will gradually replace the coal-fired boilers. Although the initial investment in the thermal power plant and the ground-source heat pump (GSHP) is large, the cost of air pollution control is low. In order to comprehensively compare the economic benefits of the integrated heating system and the coal-fired boiler heating system, the investments and costs should both be taken into account. We use the annual value method to calculate the annual cost of different heat sources. Equation (12) represents the annual cost of the heat sources and Equation (13) shows the analysis of the operating costs for the heat sources. The economic performance of the coal-fired boiler and the integrated heating system during the heating period can be analyzed by performing a comparison.

$$
A C_{\mathrm{X}}=\frac{I_{\mathrm{X}} \times r \times(1+r)^{N_{\mathrm{X}}}}{(1+r)^{N_{\mathrm{X}}}-1}+C_{\mathrm{X}}
$$

In Equation (12), $X$ represents the coal-fired boiler, the thermal power plant, the gas-fired boiler, and the GSHP in different calculations; $A C_{X}$ is the annual cost; $I_{X}$ is the initial investment; $r$ is the basic discount rate; $N_{X}$ represents the service life; and $C_{X}$ is the annual operating cost.

$$
\begin{gathered}
C_{c o a l}=\frac{Q \times T}{Q_{d d w, c} \times \eta_{c}} \times P_{c} \\
C_{C H P}=\frac{Q_{b, C H P} \times T_{b, C H P}}{Q_{d w, c} \times \eta_{C H P}} \times P_{c} \\
C_{g a s}=\frac{Q_{f} \times T_{f}}{Q_{d w o, g} \times \eta_{g}} \times P_{g} \\
C_{p}=\frac{Q_{b, p} \times T_{b, p}}{\gamma_{c o p}} \times P_{e}
\end{gathered}
$$

In Equation (13); $Q_{d w, c}$ is the low heating value of coal; $\eta_{c}$ is the coal-fired boiler efficiency; $\eta_{C H P}$ is the heating efficiency of the thermal power plant; $P_{c}$ is the unit coal price; $P_{g}$ is the unit gas price; $P_{e}$ is the electricity price when heating with a GSHP.

Environmental costs analysis: According to the standards for collecting fees for waste gas discharge, we calculate the emission charge corresponding to the reduction in the pollutant's emissions; the results are roughly equal to the environmental costs without the emission reductions. In July 2015, Shaanxi province adjusted the pollutant discharge fee levy standard of sulfur dioxide and nitrogen oxide to $\$ 0.18 / \mathrm{kg}$ pollution equivalent. If $E_{X}$ is the emission of an air pollutant (in $\mathrm{kg}$ ) and $\mu_{\mathrm{X}}$ is the pollutant equivalent value of the pollutant (in $\mathrm{kg}$ ), then the pollution equivalent of the pollutant can be expressed as:

$$
P E_{\mathrm{X}}=\frac{E_{\mathrm{X}}}{\mu_{\mathrm{X}}}
$$

The collection of the waste gas discharge fees can be calculated as:

$$
C_{e}=\sum 1.2 \times P E_{\mathrm{X}}
$$

At last, the economic benefit of the integrated heating system is given by:

$$
\Delta C=A C_{C H P}+A C_{g a s}+A C_{p}-A C_{\text {coal }}-C_{e}
$$




\section{Example Analysis}

In this section, a scenario analysis is carried out by the design of a gas peak-shaving ratio and the load ratio of the geothermal heating to the basic heating. Moreover, the environmental and economic benefit analysis models are applied to the actual situation of Xi'an City. Based on meteorological conditions, energy prices, and boiler parameter data during the winter in $\mathrm{X}^{\prime}$ an, we compare the environmental and economic benefits of the integrated heating system and the coal-fired boiler central heating system under different scenarios. The results are used to test the validity of the analysis models and verify the technical and economic advantages of the integrated heating system.

\subsection{Calculation of Heat Demand and Heating Load}

The room temperature fluctuations of office buildings and public institutions during the heating period are large and occur due to unit startup and shutdown. The heating areas of office buildings and public institutions are much lower than those of residential areas. For example, the total heating area of Xi'an in 2015 was 166,906,500 square meters and the residential heating area was 147,304,900 square meters, accounting for $88.26 \%$ of the total based on the data from '2015 urcan-rural development statistical yearbook' of China. Therefore, the example analysis only targeted heating areas for residential buildings. According to Equations (1)-(3) and empirical data, we develop curves of the changes in the heating loads, in the daily mean temperatures during the heating period, and hourly temperatures on a typical day in December in $\mathrm{Xi}^{\prime}$ an. The data are shown in Figures 3 and 4 . The heating period in $\mathrm{Xi}^{\prime}$ an is 121 days and the indoor temperature for calculation is $18^{\circ} \mathrm{C}$.

As can be seen from Figures 3 and 4, the peak-to-valley ratio of the heating load of a residential building is 2.24 during the heating period and 2.75 on a typical day. We determine the gas peak-shaving ratio by adjusting the basic heating load and conduct a scenario simulation that can meet the heating demand of residential buildings during peak times. Peak-shaving ratio is the peak-shaving point of operation, in respect to the natural gas share in the system energy demand and use. Table 1 shows the scenarios for five basic heating loads, which are $2800 \mathrm{MW}, 3000 \mathrm{MW}, 3200 \mathrm{MW}, 3400 \mathrm{MW}$, and 3500 MW. Scenario 1 and Scenario 7 will be discussed in Table 2 because their peak-shaving ratios are zero.

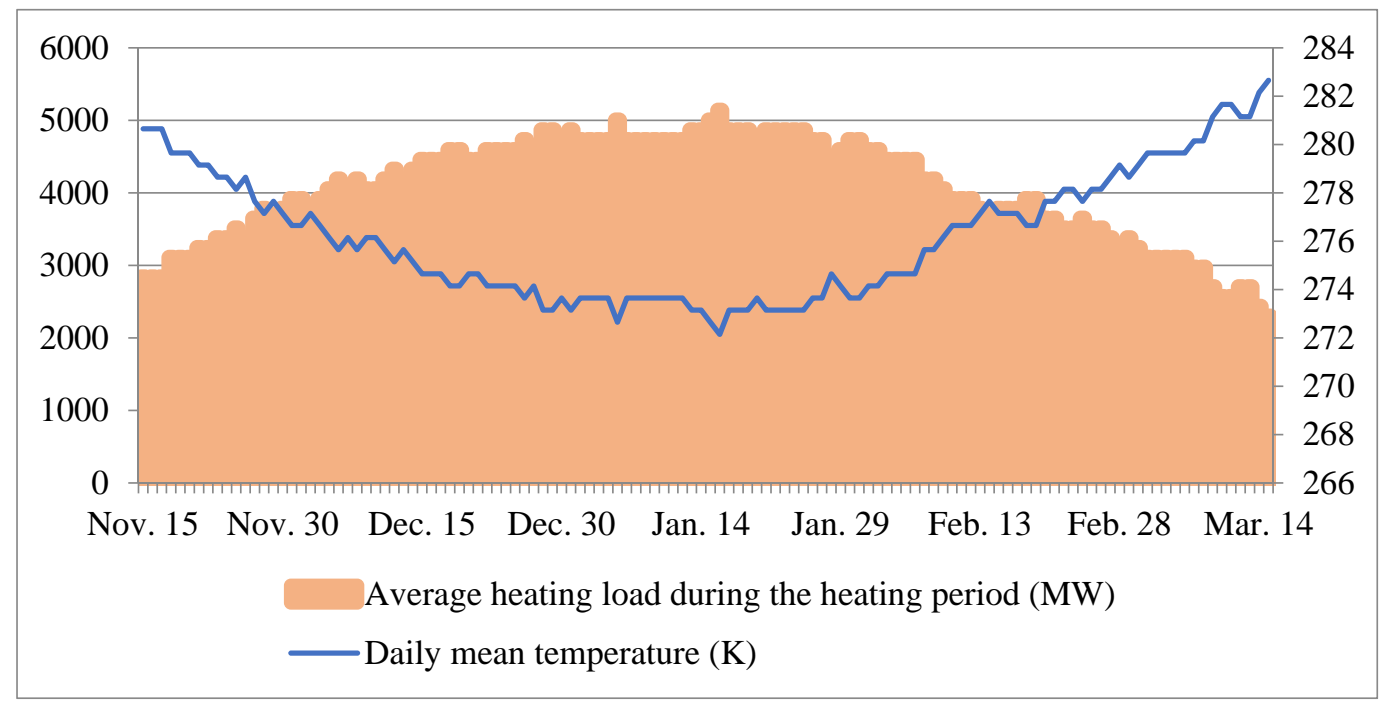

Figure 3. Daily mean temperatures and average heating loads during the heating period in Xi'an. 


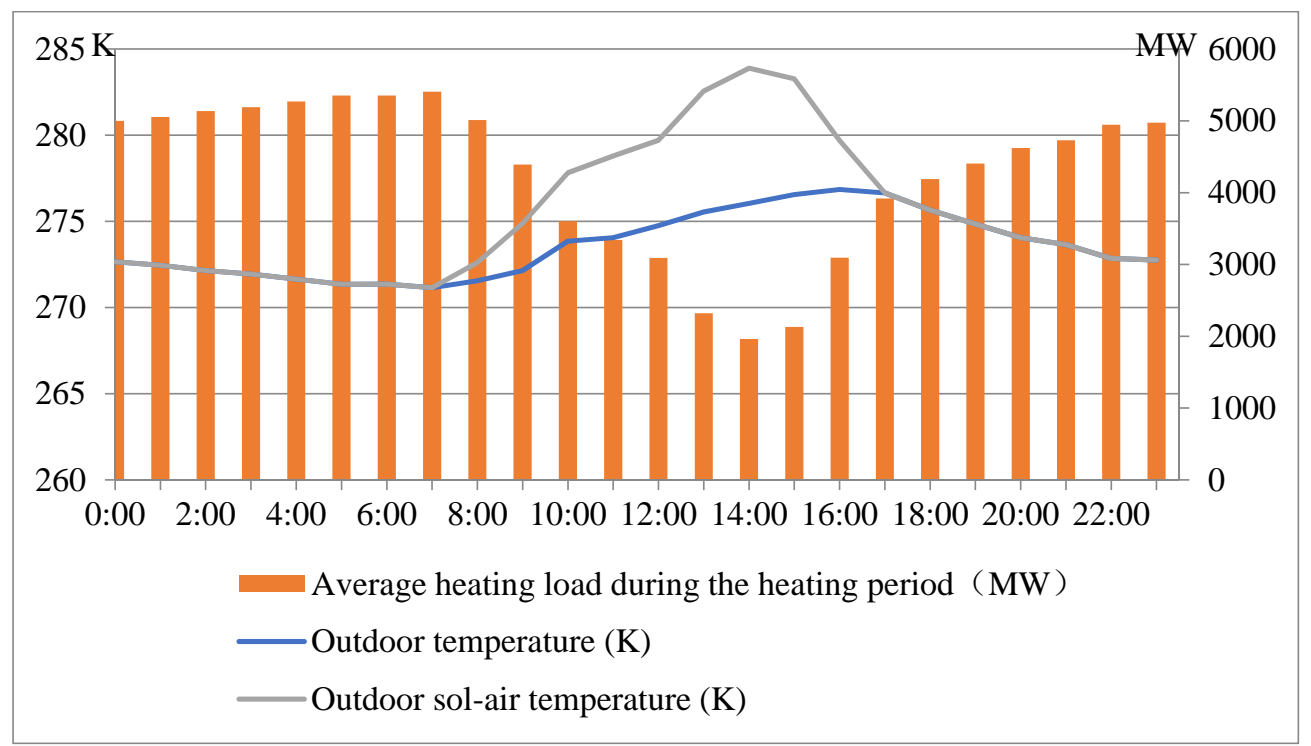

Figure 4. Hourly temperatures on a typical day and average heating loads in December in Xi'an.

Table 1. Scenario analysis of peak-shaving ratios under different basic heating loads.

\begin{tabular}{cccccc}
\hline Scenarios & $\begin{array}{c}\text { Basic } \\
\text { Heating } \\
\text { Load (MW) }\end{array}$ & $\begin{array}{c}\text { Basic Heating Load } \\
\text { Ratio during } \\
\text { Heating Period (\%) }\end{array}$ & $\begin{array}{c}\text { Gas Peak-Shaving } \\
\text { Heating Load Ratio } \\
\text { during Heating } \\
\text { Period (\%) }\end{array}$ & $\begin{array}{c}\text { Basic Heating } \\
\text { Load Ratio on a } \\
\text { Typical Day (\%) }\end{array}$ & $\begin{array}{c}\text { Gas Peak-Shaving } \\
\text { Heating Load Ratio } \\
\text { on a Typical Day } \\
\mathbf{( \% )}\end{array}$ \\
\hline Scenario 2 & 2800 & 69.02 & 30.98 & 63.63 & 36.37 \\
Scenario 3 & 3000 & 73.58 & 26.42 & 67.73 & 32.27 \\
Scenario 4 & 3200 & 77.9 & 22.1 & 71.62 & 28.38 \\
Scenario 5 & 3400 & 81.89 & 18.11 & 75.27 & 24.73 \\
Scenario 6 & 3500 & 85.58 & 14.42 & 78.78 & 21.22 \\
\hline
\end{tabular}

Table 2. Environmental benefits of the integrated heating system that is replacing the coal-fired boilers.

\begin{tabular}{|c|c|c|c|c|c|c|c|}
\hline \multirow[b]{2}{*}{ Scenarios } & \multirow{2}{*}{$\begin{array}{c}\text { Peak-Shaving } \\
\text { Ratio (\%) }\end{array}$} & \multirow{2}{*}{$\begin{array}{l}\text { GSHP to the } \\
\text { Basic Heating } \\
\text { Load Ratio (\%) }\end{array}$} & \multirow{2}{*}{$\begin{array}{l}\text { Coal } \\
\text { Consumption } \\
\text { (Million Tons) }\end{array}$} & \multirow{2}{*}{$\begin{array}{l}\text { Coal Saving } \\
\text { (Million Tons) }\end{array}$} & \multicolumn{3}{|c|}{ Emission Reductions (Million Tons) } \\
\hline & & & & & $\begin{array}{l}\text { Sulfur } \\
\text { Dioxide }\end{array}$ & $\begin{array}{c}\text { Nitrogen } \\
\text { Oxides }\end{array}$ & TSP \\
\hline Scenario 1 & 0 & 0 & 1.7236 & 0.1393 & 33.4489 & 9.7533 & 947.7186 \\
\hline Scenario 2 & 30.98 & 10 & 1.1349 & 0.7280 & 174.3540 & 49.4478 & 4950.6359 \\
\hline Scenario 3 & 26.42 & 10 & 1.2099 & 0.6530 & 156.4154 & 44.4222 & 4440.8133 \\
\hline Scenario 4 & 22.1 & 10 & 1.2809 & 0.5820 & 139.4308 & 39.6638 & 3958.1057 \\
\hline Scenario 5 & 18.11 & 10 & 1.3465 & 0.5164 & 123.7241 & 35.2635 & 3511.7164 \\
\hline Scenario 6 & 14.42 & 10 & 1.4072 & 0.4557 & 109.2134 & 31.1982 & 3099.3173 \\
\hline Scenario 7 & 0 & 10 & 1.6443 & 0.2186 & 52.4724 & 15.3018 & 1486.7180 \\
\hline
\end{tabular}

The total heating load of Xi'an has risen steadily in recent years. In addition, the heating capacity of thermal power plants has increased significantly and has surpassed the heating capacity of boiler rooms in 2015. Both heat sources can meet the residential heating demand. Although the heating efficiency of thermal power plants is low, it has a great potential for growth. Xi'an has an abundance of geothermal energy; however, the developed geothermal wells currently are mostly used for domestic water and bathing and the energy utilization rate is low. In addition, the use of shallow geothermal energy for heating is still in the initial stages of development. Limited by space, terrain, and other restrictions, buildings that are suitable for the installation of ground-source heat pumps are mostly office buildings, villas, high-end residential area, etc. As far as we know, in 2015, the residential heating area in $\mathrm{Xi}^{\prime}$ an accounted for $88.26 \%$ of its total heating area; therefore, we use Xi'an's residential building central heating for the analysis and assume that the future heating load of geothermal energy will account for about $10 \%$ of the total basic load. 


\subsection{Environmental Benefit Evaluation Model}

In order to determine the annual environmental benefits of the integrated heating system that substitute the coal-fired boilers, we carry out a scenario analysis by assuming that the geothermal heating load accounts for $10 \%$ of the basic heating load and that the remainder of the basic heating load is provided by thermal power plants. Using the environmental benefit analysis model, the air pollutant emission coefficients, and the boiler parameters, we calculate the emission reductions. The results are shown in Table 2. If all the loads are provided independently by the coal-fired boilers, the coal consumption is equivalent to 1.8629 million tons of standard coal as calculated by formula 5 .

Table 2 indicates that the energy-savings of the integrated heating system are related to the peak-shaving ratio $(\alpha)$ and the ratio of the GSHP to the basic heating load $(\beta)$. The larger the ratios, the higher the annual coal savings are. In addition, the energy-saving effect is higher for the gas-fired boiler that for the ground-source heat pump.

\subsection{Economic Benefit Analysis}

In this section, we use the residential heating of Xi'an in 2015 as an example to compare and analyze the economic benefits of the integrated heating system and the coal-fired boilers. According to the economic benefit analysis model, we first determine the initial investment and annual operating costs of the two systems. The construction cost per square meter is selected as an index of the initial investment of the heat sources. The construction costs per square meter for the cogeneration, the gas-fired boiler, and the coal-fired boiler are fixed at $\$ 32, \$ 16$, and $\$ 27$, respectively according to a company in $\mathrm{Xi}^{\prime}$ an. While the construction cost of the GSHP changes with heating area, the larger the heating area, the lower the construction cost per square meter is. In other words, the cost differs for different types and sizes of buildings. In the integrated heating system, the GSHP is installed under the buildings; therefore, the construction cost per unit area is $\$ 31.27 / \mathrm{m}^{2}$. For the operating cost, we use the fuel cost as an individual index because the fuel cost accounts for about $70 \%$ of the operating costs. The basic discount rate is assumed to be $6 \%$ and the service life for the equipment is 20 years. Finally, the actual economic benefits analysis model is added to the actual data to calculate the annual economic benefits of the integrated heating system, as shown in Table 3.

Table 3. Economic benefits of the integrated heating system that replaces the coal fired boilers.

\begin{tabular}{ccccccc}
\hline Scenarios & $\begin{array}{c}\text { Peak-Shaving } \\
\text { Ratio (\%) }\end{array}$ & $\begin{array}{c}\text { GSHP tor the } \\
\text { Basic Heating } \\
\text { Load Ratio (\%) }\end{array}$ & $\begin{array}{c}\text { Initial } \\
\text { Investment }\end{array}$ & $\begin{array}{c}\text { Peak-Shaving } \\
\text { Ratio (\%) }\end{array}$ & $\begin{array}{c}\text { GSHP tor the } \\
\text { Basic Heating } \\
\text { Load Ratio (\%) }\end{array}$ & $\begin{array}{c}\text { Initial } \\
\text { Investment }\end{array}$ \\
\hline Scenario 1 & 0 & 0 & 4698.33 & 150.19 & 559.82 & 63.94 \\
Scenario 2 & 30.98 & 10 & 4429.2 & 268.66 & 654.82 & 42.14 \\
Scenario 3 & 26.42 & 10 & 4536.32 & 252.32 & 647.82 & 44.91 \\
Scenario 4 & 22.1 & 10 & 4637.81 & 236.85 & 641.20 & 47.54 \\
Scenario 5 & 18.11 & 10 & 4731.54 & 222.54 & 635.06 & 49.97 \\
Scenario 6 & 14.42 & 10 & 4818.22 & 209.33 & 629.4 & 52.22 \\
Scenario 7 & 0 & 10 & 5156.97 & 157.64 & 607.25 & 61 \\
\hline
\end{tabular}

For the coal-fired boiler, the annual cost is 507.59 USD million and the pollutant charge is 6910.71 USD million as calculated by formulas (12)-(15). Relatively speaking, the annual cost of the integrated heating system increases slowly as the gas peak-shaving ratio rises (Table 3 ). When the peak-shaving ratio is in the range of $0 \sim 30.98 \%$, the annual cost of the integrated heating system is 1.2 to 1.29 times than that the cost of a coal-fired boiler. However, a significant reduction in the total quantity of air pollutant emissions occurs when the integrated heating system is used; thus the difference between the heat costs will be further reduced after considering the pollutant charges. In addition, the coal-fired boilers are costlier to construct and require higher labor maintenance cost; therefore, their unit heating operation cost is far higher than for the integrated heating system. In conclusion, 
due to a variety of factors, the economic benefits of the integrated heating system are higher compared to central heating using coal-fired boilers.

\section{Sensitivity Analysis}

\subsection{Sensitivity Analysis of Heat Sources to the Price Factors}

After the reform of the retail electricity market and the marketization of the natural gas price, the electricity and gas prices on the retail side will be determined by the market according to the policy of "control the middle, release both sides" in China. The price fluctuation will result in a cost risk for the integrated heating system; for example, the natural gas price directly impacts the heating cost of a gas-fired peak-shaving boiler and the electricity price impacts the operating cost of a ground-source heat pump. Additionally, the price fluctuation of coal is more volatile compared to the prices for gas and electricity. This results in overall fluctuations of the operating costs for the integrated heating system.

The parameter sensitivity of the energy consumption economy of a coal-fired boiler refers to the degree of influence that a parameter has on the boiler's cost; that is to say, the changes in the annual cost are caused by the changes in the parameter. The parameter sensitivity is a dimensionless quantity. We choose the coal price for a single-factor sensitivity analysis of the coal-fired boiler cost and use the coal price, gas price, and the electricity price as parameters to conduct a single-factor sensitivity analysis of the integrated heating system cost. In addition, we comparatively analyze the main factors affecting the economy of the integrated heating system. Specifically, we select scenario 4 for the simulation object and set the change range of the factors as $-10 \sim 10 \%$. We calculate the changes in the annual cost of the different heat sources for the changes in the factors and calculate the sensitivity coefficient of the factors. In formula (17), we assume that $\Delta A$ is the corresponding change rate of the evaluation index $(A)$ when the uncertain factors $(X)$ change $\Delta X ; \Delta X=20 \%$ in our calculation.

$$
\phi=\Delta A / \Delta X
$$

As shown in Figure 5, the annual cost of the coal-fired boiler will increase or decrease by $1.6 \%$ in the same direction for every $5 \%$ increase or decrease in the coal price. That is to say, at the current level of coal price, the sensitivity coefficient of the annual cost of the coal-fired boiler to the coal price is 0.32 calculated by Equation (17). On the other hand, Figure 6 indicates that, as the coal, gas, and electricity prices increase or decrease by $5 \%$, the annual cost of the integrated heating system changes in the same direction by $0.82 \%, 0.89 \%$, and $0.14 \%$ respectively. Correspondingly, the sensitivity coefficients are respectively $0.164,0.178$, and 0.027 , values that are less than the sensitivity coefficient of the annual cost of the coal-fired boiler to the coal price. Moreover, we find that among the sensitive factors accounting for the integrated heating system, the impact of the gas price is the greatest, while the impact is considerably less for the electricity price compared to of the prices of gas and coal.

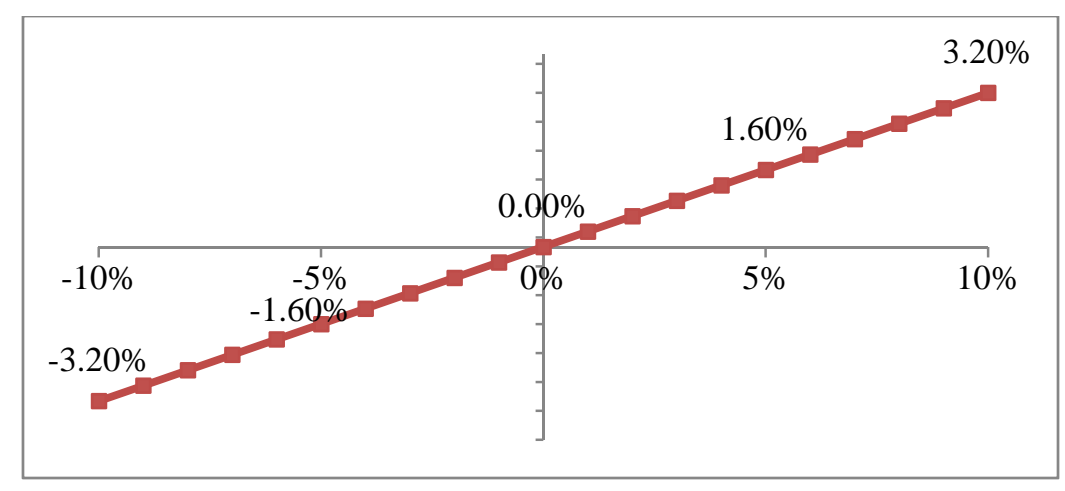

Figure 5. Annual changes in the cost of the central heating boiler under fluctuating coal prices. 


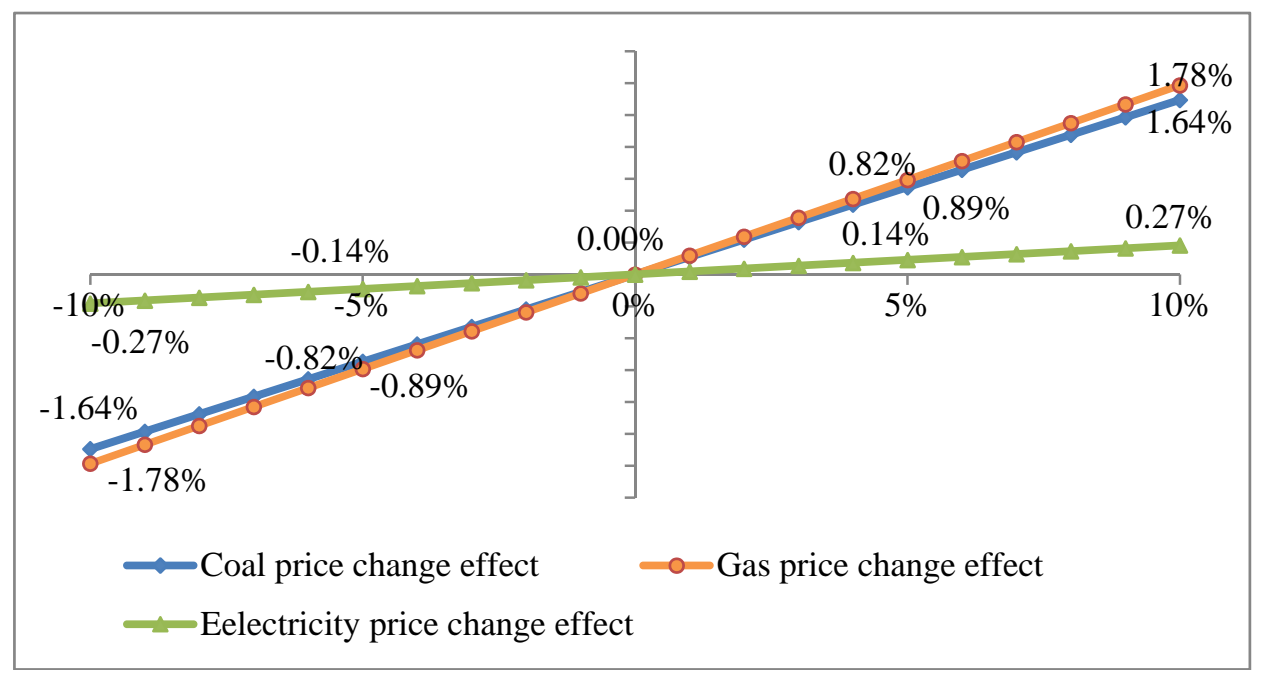

Figure 6. Annual changes in the cost of the integrated heating system under the fluctuating coal, gas, and electricity prices.

\subsection{Sensitivity Analysis of Heat Sources to the Load Ratios}

The proportion of components of the heating load to the total heating load of the integrated heating system changes based on the demand in heating load and the heating load curves. Therefore, the peak-shaving ratio provided by the gas-fired peak-shaving boiler is calculated as $\alpha=Q_{f} / Q$ and the ratio of the GSHP heating load to the basic heating load is given by $\beta=Q_{b, p} /\left(Q_{b, C H P}+Q_{b, p}\right)$. Because the isolated operation mode for the GSHP will result in a decrease in soil temperatures, thus affecting the sustainable use of the heat pumps. $\beta$ should be adjusted to the optimal proportion to satisfy the heating demand and the soil environment requirements.

First of all, we conduct a scenario analysis on the heating costs including fuel cost, pollutant charges, and other variable costs. We use the following data: Shaanxi industrial natural gas price $\left(\$ 0.35 / \mathrm{m}^{3}\right)$, Guanzhong $5000 \mathrm{kcal}$ power coal price $(\$ 62.24 /$ ton), gas-fired boiler thermal efficiency $(98 \%)$, residential building area $\left(146,654,900 \mathrm{~m}^{2}\right)$, and monthly fee per square meter for Xi'an residents $\left(\$ 0.88 / \mathrm{m}^{2}\right)$. We use $\$ 0.18 /$ pollution equivalent as the fee for the pollutant charges of sulfur dioxide and nitrogen oxide. The analysis is displayed in Table 4.

Table 4. Scenario analysis of heating cost under various peak-shaving ratios.

\begin{tabular}{ccccccc}
\hline Scenarios & $\begin{array}{c}\text { Peak-Shaving } \\
\text { Ratio (\%) }\end{array}$ & $\begin{array}{c}\text { Fuel Cost of } \\
\text { Thermal } \\
\text { Power Plant } \\
\text { (USD million) }\end{array}$ & $\begin{array}{c}\text { Fuel Cost of } \\
\text { Gas-Fired } \\
\text { Boiler (USD } \\
\text { million) }\end{array}$ & $\begin{array}{c}\text { Pollutant } \\
\text { Charge of } \\
\text { Thermal } \\
\text { Power Plant } \\
\text { (USD million) }\end{array}$ & $\begin{array}{c}\text { Pollutant } \\
\text { Charge of } \\
\text { Gas-Fired } \\
\text { Boiler (USD } \\
\text { million) }\end{array}$ & $\begin{array}{c}\text { Residential } \\
\text { Heating } \\
\text { Expenditure } \\
\text { (USD million) }\end{array}$ \\
\hline Scenario 1 & 0 & 150.19 & 0 & 63.94 & 0 & 285.67 \\
Scenario 8 & 14.42 & 128.54 & 74.41 & 54.72 & 0.02 & 285.67 \\
Scenario 9 & 18.11 & 122.99 & 93.45 & 52.36 & 0.02 & 285.67 \\
Scenario 10 & 22.1 & 117.00 & 114.04 & 49.81 & 0.03 & 285.67 \\
Scenario 11 & 26.42 & 110.51 & 136.33 & 47.05 & 0.03 & 285.67 \\
Scenario 12 & 30.98 & 103.66 & 159.86 & 44.13 & 0.04 & 285.67 \\
\hline
\end{tabular}

We use Crystal Ball software, a suite of easy-to-use Microsoft Excel add-in software, to analyze the sensitivity of the investment cost to the gas-fired boiler peak-shaving ratio. Crystal Ball is a graphically oriented forecasting and risk analysis program. It uses the Monte-Carlo technique to perform uncertainty and sensitivity analyses [46,47]. We assume that the heating demand of residential buildings conforms to a normal distribution with $\mu=42,558,184, \sigma=12,413,894.67$ during 
the heating period. After 5000 simulated operations, the sensitive analysis of the heating fuel cost to the peak-shaving ratio is shown in Figure 7.

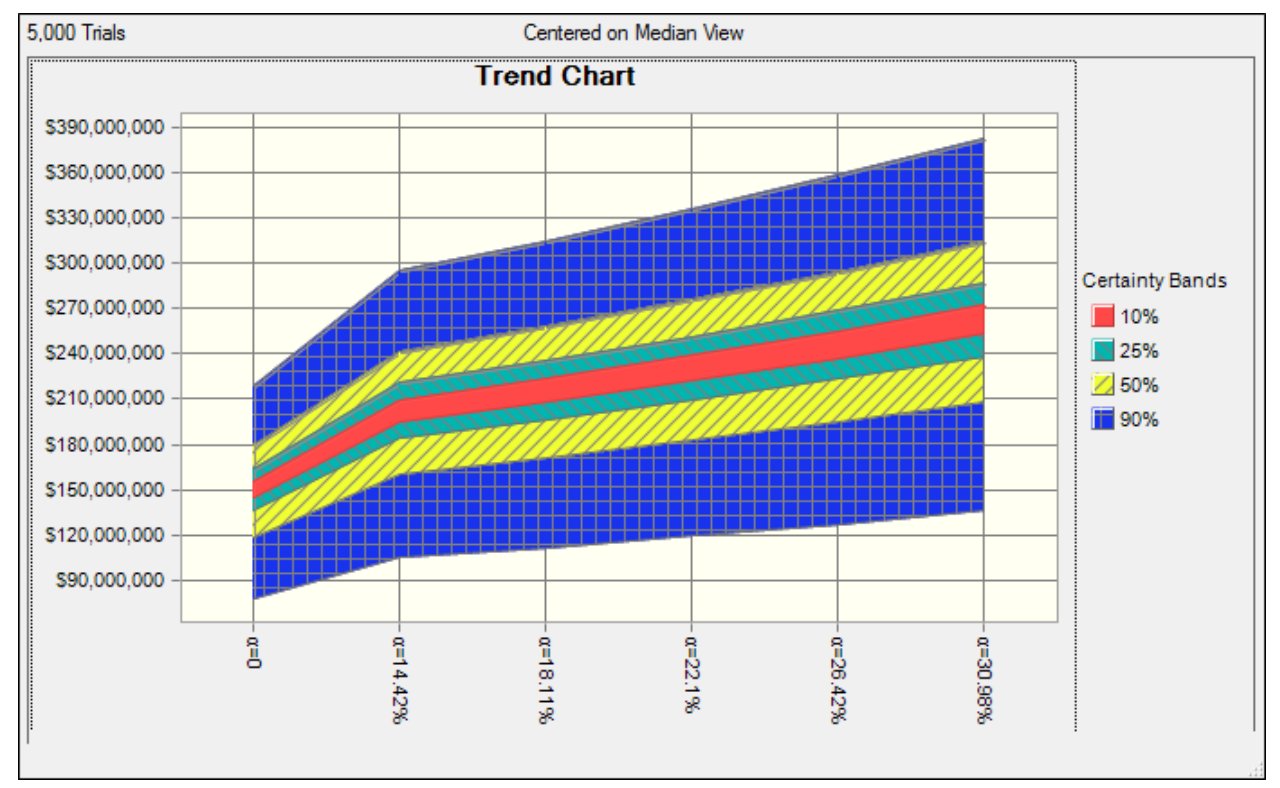

Figure 7. Diagram of sensitivity of fuel cost to peak-shaving ratio.

In addition, due to the peak-shaving of the gas-fired boiler, the reduction in air pollutants results in the reduction of pollutant charges. Therefore, we further consider the pollutant charges and analyze the sensitivity of the pollutant charges to the peak-shaving ratio as shown in Figure 8.

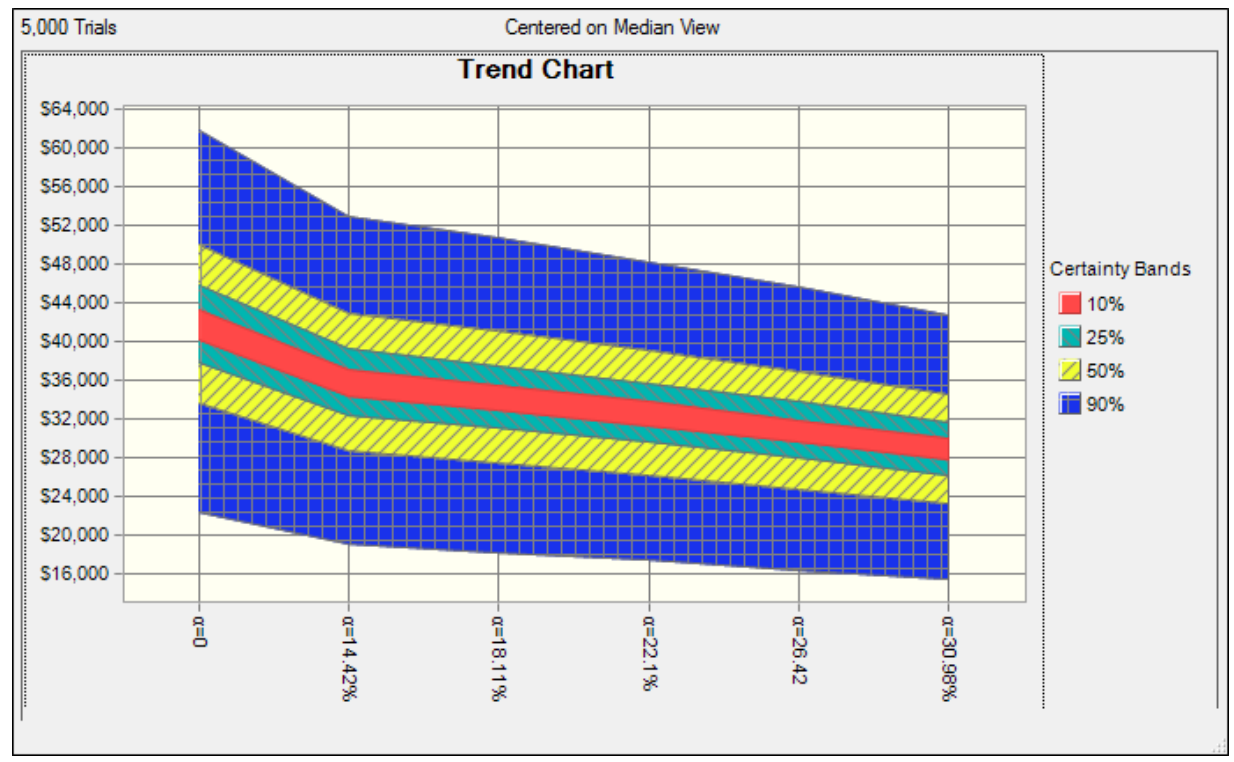

Figure 8. Sensitivity Diagram of pollutant charges to peak-shaving ratio.

As can be seen from Figures 7 and 8, the fuel cost increases with the increase in the peak-shaving ratio, while the pollutant charge decreases with the increase in the peak-shaving ratio; the increase in the fuel cost is greater than the decrease in the pollutant charges. Also, when the peak-shaving ratio increases, the possibility of an increase in the fuel cost will be greater $(90 \%)$. This indicates that the fuel 
cost of the gas-fired boiler influences the integrated heating system the most; therefore, when the gas peak-shaving ratio exceeds a certain proportion, the heating costs will rise dramatically.

\section{Conclusions}

An integrated heating system incorporating geothermal energy is in line with the demands of the socio-economic development and environmental protection of cities. Using winter heating in $\mathrm{Xi}^{\prime}$ an in China as an example, this study conducts a scenario analysis by determining heat load proportions for different heat sources and calculating the environmental and economic benefits of the integrated heating system and coal-fired boilers under different scenarios. Sensitivity analyses of the heat source to the price factors and the load ratios are conducted. The results indicate that the operating costs of the integrated heating system are most sensitive to the natural gas price and the gas peak-shaving ratio. Accordingly, the optimum natural gas peak-shaving ratio can be determined.

In addition, in this study, we also conduct a comparison of the heating cost of the integrated heating system and the coal-fired boiler regarding the fuel cost and the pollutant charges. By assuming that residential heating demands conform to a normal distribution, we use Crystal Ball software for a sensitivity analysis of the investment costs to the peak-shaving ratio $(\alpha)$ of the gas-fired boiler. Finally, we determine the trends for the fuel cost and pollutant charges as a result of changes in the peak-shaving ratio and conclude that the fuel cost of the gas-fired boiler has the greatest impact on operating costs of the integrated heating system.

This paper mainly considers operating costs without considering depreciation costs, environmental costs, etc., because the operating costs of heating systems account for a high proportion of total cost, especially the fuel costs. Heating units consume a large amount of natural gas and other fuels with high price, thus the fuel costs are very high, for example, the fuel cost of gas-fired units even up to $70 \%$ [48]. Also, the sensitivity analysis in this paper is mainly carried out in consideration of fuel cost and other operating costs. It is believed that the total cost is also in line with such analysis.

The integrated heating system that incorporates geothermal energy requires the co-construction of a heat supply network, gas network, and power grid. The transportation distances differ for the integrated heating network and the coal-fired boiler. Nevertheless, in this study, we do not consider the power consumption of the pipeline transportation and the heat loss of the pipelines because they have little impact on the environmental and economic benefits. We believe that in the future, the integrated heating system will have great prospects for development due to the reduction in initial investment in the cogeneration and the GSHP and due to increased access to wind power, photovoltaic power, and other renewable energy sources.

Acknowledgments: This work has been supported by the project "Special Items Fund of Beijing Municipal Commission of Education" (16JDGLB023) and "Fundamental Research Funds for the Central Universities" (2017XS105).

Author Contributions: Qingyou Yan analyzed the data and conclusion; Chao Qin designed the model and wrote the paper.

Conflicts of Interest: The authors declare no conflict of interest. The founding sponsors had no role in the design of the study; in the collection, analyses, or interpretation of data; in the writing of the manuscript, and in the decision to publish the results.

\section{References}

1. Guiding Opinions of the State Council on Promoting "Internet +" Action; The State Council: Beijing, China, 2015. (In Chinese)

2. Jia, H.; Wang, D.; Xu, X.; Yu, X. Research on some key problems related to integrated energy system. Autom. Electr. Power Syst. 2015, 39, 198-207. (In Chinese)

3. Dong, Z.; Zhao, J.; Wen, F.; Xue, Y. From smart grid to Energy Internet: Basic concept and research framework. Autom. Electr. Power Syst. 2014, 38, 1-11. (In Chinese) 
4. Mehleri, E.D.; Sarimveis, H.; Markatos, N.C.; Papageorgiou, L.G. A mathematical programming approach for optimal design of distributed energy systems at the neighbourhood level. Energy 2012, 44, 96-104. [CrossRef]

5. Zhou, Z.; Liu, P.; Li, Z.; Ni, W. An engineering approach to the optimal design of distributed energy systems in China. Appl. Therm. Eng. 2013, 53, 387-396. [CrossRef]

6. Gu, W.; Wu, C.; Wang, J.; Lu, S.; Luo, Z. Optimal operation for integrated energy system considering thermal inertia of district heating network and buildings. Appl. Energy 2017, 199, 234-246. [CrossRef]

7. Guo, P.; He, M.; Zheng, L.; Zhang, N. A geothermal recycling system for cooling and heating in deep mines. Appl. Therm. Eng. 2017, 116, 833-839. [CrossRef]

8. Sobhy, I.; Brakez, A.; Benhamou, B. Energy performance and economic study of a solar floor heating system for a Hammam. Energy Build. 2017, 141, 247-261. [CrossRef]

9. Wang, H. Study on Peak-Shaving Heating Modes of Combined District Heating Systems and the Comprehensive Optimization. Ph.D. Thesis, Harbin Institute of Technology, Harbin, China, 2013. (In Chinese)

10. Jia, H.; Mu, Y.; Yu, X. Thought About the Integrated Energy System in China. Electr. Power Constr. 2015, 36, 16-25. (In Chinese)

11. Liu, L.; Qu, N.; Cao, Y. Economic Analysis of Combined Heat and Power. Technol. Enterp. 2014, 173. [CrossRef]

12. Shabbir, I.; Mirzaeian, M. Carbon Emissions Reduction Potentials in Pulp and Paper Mills by Applying Cogeneration Technologies. Energy Procedia 2017, 112, 142-149. [CrossRef]

13. Tomofuji, D.; Morimoto, Y.; Sugiura, E.; Ishii, T.; Akisawa, A. The prospects of the expanded diffusion of cogeneration to 2030-Study on new value in cogeneration. Appl. Therm. Eng. 2016, 114, 1403-1413. [CrossRef]

14. Zhang, J. Geothermal Energy, Heat and Heat Pump Technology; Chemical Industry Press: Beijing, China, 2014. (In Chinese)

15. Kaldehi, B.J.; Keshavarz, A.; Pirooz, A.A.S.; Batooei, A.; Ebrahimi, M. Designing a micro Stirling engine for cleaner production of combined cooling heating and power in residential sector of different climates. J. Clean. Prod. 2017, 154, 502-516. [CrossRef]

16. Meybodi, M.A.; Behnia, M. Impact of carbon tax on internal combustion engine size selection in a medium scale CHP system. Appl. Energy 2011, 88, 5153-5163. [CrossRef]

17. Wang, J.; Zhai, Z.; Jing, Y.; Zhang, C. Optimization design of BCHP system to maximize to save energy and reduce environmental impact. Energy 2010, 35, 3388-3398. [CrossRef]

18. Abdurafikov, R.; Grahn, E.; Kannari, L.; Ypyä, J.; Kaukonen, S.; Heimonen, I.; Paiho, S. An analysis of heating energy scenarios of a Finnish case district. Sustain. Cities Soc. 2017, 32, 56-66. [CrossRef]

19. Sharma, A.K.; Sharma, C.; Mullick, S.C.; Kandpal, T.C. Solar industrial process heating: A review. Renew. Sustain. Energy Rev. 2017, 78, 124-137. [CrossRef]

20. Zhao, D.; Ji, J.; Yu, H.; Wei, W.; Zheng, H. Numerical and experimental study of a combined solar Chinese kang and solar air heating system based on Qinghai demonstration building. Energy Build. 2017, 143, 61-70. [CrossRef]

21. Alam, M.M.R.; Behfar, A.; Shahmoradi, R. Potential Application of Solar Power Systems for Residential Buildings in High-Density Urban Pattern: The Case of the Eixample District, City of the Barcelona, in Spain. In Recent Researches in Environmental and Geological Sciences; WSEAS Press: Kos Island, Greece, 2012; pp. 342-347, ISBN 978-1-61804-110-4.

22. Muniak, D.; Wabik, K.; Korzen, A. Analysis of the cost of preparation of domestic hot water in a single-family home, taking account of the subvention under the Limitations of Low Emission Programme in Krakow. Dist. Heat. Heat. Ventilation 2017, 2, 63-71.

23. Muniak, D. The Impact of the Requirements Of Limitation of Low Emission Programme in Krakow on the EP Factor Value. Dist. Heat. Heat. Ventilation 2017, 5, 192-195.

24. Badami, M.; Gerboni, R.; Portoraro, A. Determination and assessment of indices for the energy performance of district heating with cogeneration plants. Energy 2017, 127, 697-703. [CrossRef]

25. Dai, Y.; Chen, J. Solar Cogeneration/Trigeneration. In Encyclopedia of Sustainable Technologies, 1st ed.; Elsevier: Amsterdam, The Netherlands, 2017; pp. 357-366, ISBN 9780128047927.

26. Febrianto, R.; Thain, I.; Zarrouk, S.J. The geothermal heating system at Taupo Hospital, New Zealand. Geothermics 2016, 59, 347-356. [CrossRef]

27. Islam, S.; Dincer, I. Development, analysis and performance assessment of a combined solar and geothermal energy-based integrated system for multigeneration. Sol. Energy 2017, 147, 328-343. [CrossRef] 
28. Kaushal, M. Geothermal cooling/heating using ground heat exchanger for various experimental and analytical studies: Comprehensive review. Energy Build. 2017, 139, 634-652. [CrossRef]

29. Tester, J.W.; Reber, T.J.; Beckers, K.F.; Lukawski, M.Z. 4: Deep Geothermal Energy for District Heating: Lessons Learned from the U.S. and beyond. In Advanced District Heating and Cooling (DHC) Systems; Wiltshire, R., Ed.; Woodhead Publishing: Oxford, UK, 2016; pp. 75-98.

30. Lucia, U.; Simonetti, M.; Chiesa, G.; Grisolia, G. Ground-source pump system for heating and cooling: Review and thermodynamic approach. Renew. Sustain. Energy Rev. 2016, 70, 867-874. [CrossRef]

31. Lund, J.W.; Boyd, T.L. Direct utilization of geothermal energy 2015 worldwide review. Geothermics 2016, 60, 66-93. [CrossRef]

32. Keçebaş, A.; Coskun, C.; Oktay, Z.; Hepbasli, A. Comparing advanced exergetic assessments of two geothermal district heating systems for residential buildings. Energy Build. 2014, 81, 141-151. [CrossRef]

33. Keçebaş, A.; Hepbasli, A. Conventional and advanced exergoeconomic analyses of geothermal district heating systems. Energy Build. 2014, 69, 434-441. [CrossRef]

34. Keçebaş, P.; Gökgedik, H.; Alkan, M.A.; Keçebaş, A. An economic comparison and evaluation of two geothermal district heating systems for advanced exergoeconomic analysis. Energy Convers. Manag. 2014, 84, 471-480. [CrossRef]

35. Kyriakis, S.A.; Younger, P.L. Towards the increased utilization of geothermal energy in a district heating network through the use of a heat storage. Appl. Therm. Eng. 2016, 94, 99-110. [CrossRef]

36. Yamankaradeniz, N. Thermodynamic performance assessments of a district heating system with geothermal by using advanced exergy analysis. Renew. Energy 2016, 85, 965-972. [CrossRef]

37. Arat, H.; Arslan, O. Optimization of district heating system aided by geothermal heat pump: A novel multistage with multilevel ANN modelling. Appl. Therm. Eng. 2017, 111, 608-623. [CrossRef]

38. Arat, H.; Arslan, O.; Lund, H.; Kaiser, M.J. Exergoeconomic analysis of district heating system boosted by the geothermal heat pump. Energy 2017, 119, 1159-1170. [CrossRef]

39. Keçebaş, A. Exergoenvironmental analysis for a geothermal district heating system: An application. Energy 2016, 94, 391-400. [CrossRef]

40. Yürüsoy, M.; Keçebaş, A. Advanced exergo-environmental analyses and assessments of a real district heating system with geothermal energy. Appl. Therm. Eng. 2016, 113, 449-459. [CrossRef]

41. Martín-Gamboa, M.; Iribarren, D.; Dufour, J. On the environmental suitability of high- and low-enthalpy geothermal systems. Geothermics 2015, 53, 27-37. [CrossRef]

42. Aslan, A.; Yüksel, B.; Akyol, T. Effects of different operating conditions of Gonen geothermal district heating system on its annual performance. Energy Convers. Manag. 2014, 79, 554-567. [CrossRef]

43. Noorollahi, Y.; Arjenaki, H.G.; Ghasempour, R. Thermo-economic modeling and GIS-based spatial data analysis of ground source heat pump systems for regional shallow geothermal mapping. Renew. Sustain. Energy Rev. 2017, 72, 648-660. [CrossRef]

44. Song, J.; Wallin, F.; Li, H. District heating cost fluctuation caused by price model shift. Appl. Energy 2017, 194, 715-724. [CrossRef]

45. Yan, S.; Li, S.; Li, H. Analysis of geo-temperature recovery under intermittent operation of ground-source heat pump. Energy Build. 2011, 43, 935-943.

46. Zhao, W. Application of crystal ball software in management simulation. In Proceedings of the International Conference on Computer Science and Service System, Nanjing, China, 27-29 June 2011; pp. 2099-2101.

47. Abhishek, B.; Ashok, K. Application of the Crystal Ball ${ }^{\circledR}$ software for uncertainty and sensitivity analyses for predicted concentration and risk levels. Environ. Prog. Sustain. Energy 2010, 27, 289-294.

48. Tian, T. Technical and Economic Analysis of Gas Power Plant on Power Peaking; North China Electric Power University: Beijing, China, 2015. (In Chinese)

(C) 2017 by the authors. Licensee MDPI, Basel, Switzerland. This article is an open access article distributed under the terms and conditions of the Creative Commons Attribution (CC BY) license (http://creativecommons.org/licenses/by/4.0/). 